\title{
Attributions Made By Students In Learning Groups
}

\author{
Jerry L. Geisler, (E-mail: geislerj@mscd.edu), Metropolitan State College of Denver
}

\begin{abstract}
Student groups are widely used for major projects in the business capstone course. Increasingly, students are expressing difficulties with such groups primarily involving arrangements for meetings outside of class and group relationships. This preliminary research explored social loafing and the attributions made by students about its causes. It was widespread, but just talking about social loafing improved the group's reaction to it. Satisfaction with the group experience was not adversely affected by the presence of social loafing in groups.
\end{abstract}

\section{Introduction}

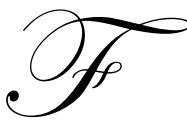

or nearly thirty years, I have used group projects in the capstone, strategic management, course that is required of all business majors. In groups, students perform a strategic audit of a publicly traded corporation that amounts to 20 to 50 percent of the course grade. This requirement mimics my undergraduate and graduate business educational experiences. Contrary to appearances I am not just "getting even" for having had to go through the experience myself! There is a lot more going on in groups than just writing large reports.

Other writers (Bowen and Jackson, 1985/86) said it remarkably well:

The issue as we see it is simply that managers and professionals will be working in groups for the rest of their lives. The complexity of most modern organizational tasks, the necessity for broad participation to achieve commitment to programs, and the isolation resulting from task specialization in organizations require group forms of organizing (committees, task forces, project teams, boards, etc.) to achieve coordination on projects. No single person, working alone, can float a bond issue, produce a jet fighter, or market a new laundry detergent. The more important the project or issue with respect to the organization's priorities, the more likely that a group will be needed to tap the energies, ideas, resources, and involvement of numerous mangers and technical specialists. In short, "group smarts" have become survival skills for the modern professional or manager!

We expect students to learn several things during the various phases of the project. There is, of course, the desired learning of concepts and theories of strategic management. A byproduct of doing the project is the sharpening of management skills like planning, leading, organizing, and controlling. These functional activities become the framework for developing technical, conceptual, and interpersonal skills that are essential for future success as a manager. Interpersonal skills like communication, conflict resolution, and analyzing group influences develop from participating in situations where those issues arise as a matter of the course of events. One issue about learning, however, is the conclusion reached by a researcher: "At the university-level, there is very little empirical evidence regarding the effect of student learning teams on learning achievement (Rusth, 2000)."

Other researchers, however, reached a conclusion that has great implications for all educators. It was:

Readers with comments or questions are encouraged to contact the author via email. 
The results of this study suggest that if teachers apply what they know about complex systems in general to the design of management education systems in particular, they may be able to enhance learning, the likelihood that students will apply what they learn, and student satisfaction with the educational experience, despite competing expectations and diverse abilities (Lengnick-Hall and Sanders, 1997).

In other words, professors who apply their knowledge and expertise in designing the learning experience should have a significant impact on the results achieved. It is likely that most professors are trying to do this. Aside from classroom barriers, however, there is another consideration.

A classic article by Chris Argyris explained why smart people find it the hard to learn. In talking about consultants, he wrote:

The professionals began to feel embarrassed. They were threatened by the prospect of critically examining their own role in the organization. Indeed, because they were so well paid (and generally believed that their employers were supportive and fair), the idea that their performance might not be at its best made them feel guilty. Far from being a catalyst for real change, such feelings caused most to react defensively. The projected the blame for any problems away from themselves and onto what they said were unclear goals, insensitive and unfair leaders, and stupid clients (Argyris, 1975).

A fascinating aspect of the Argyris quote is that it illustrates a common attribution bias, i.e., self-serving bias. This means that the consultants would readily take credit for successes, but were prone to blame the situation and/or others for a lack of success. The self-serving bias and the fundamental attribution error, over attributing cause to dispositional reasons and under attributing cause to situational reasons, represent clear barriers to learning from experience and group activities (Gibson, Ivancevich, Donnelly, and Konopaske, 2003). These concepts need further elaboration.

\section{Attribution Theory}

Attribution theory focuses on how people attempt to (1) understand the causes of a certain event, (2) assess responsibility for the outcomes of the event, and (3) evaluate the personal qualities of the people involved in the event (Schermerhorn, Hunt, and Osborn, 2000). They go on to say that we are especially concerned with whether one's behavior has been externally or internally caused. Internal causes are matters under the control of the individual like motivation, ability, and effort. External causes are outside the person and reflect the impact of the immediate situation or the environment.

In deciding to make an internal or external attribution of the cause of a behavior, there are three criteria proposed by Kelley:

1. Consensus. Would most other people say or do the same thing in this situation? If so, we would be less likely to attribute the behavior to internal causes.

2. Distinctiveness. Is the behavior unusual or atypical for that person? If so, then we would infer that some situational factor must be responsible.

3. Consistency. Does the person engage in the behavior consistently? When consistent the behavior is likely to be seen as internally caused (Gibson, et al, 2003).

There are biases in making attributions. This means that an individual favors one type (internal or external) over another. As mentioned above, the fundamental attribution error is caused by having insufficient information to make the "correct" attribution. The self-serving bias is caused by faulty recall or selective perception that lets us remember the good and forget the bad things about our behavior (Gibson, et al, 2003). Another bias, actor-observer, results when a person attributes the behavior of others to personal traits and his or her own behavior to situational factors. 
Why should we care at all about attributions or errors in making them? In the first place, the act of making an attribution has consequences. The message or meaning of an attribution will be communicated either directly or indirectly to the target person. The truth or falsity of the attribution will be evaluated and, whether the attribution was accurate or not, the target will have an emotional or behavioral response. Secondly, some individuals will make an attribution- subject to the biases above- and then act on it without knowing whether it is true or not. In other words, a student learning group might observe that one of its members had not attended meetings and had not completed early assignments. Then, they may make an attribution that the student's low output was the result of laziness. They will try to change the student's behavior through controlling it by requiring more meetings! Upon intervening in such cases, I have often found that the student had communicated his or her schedule to the group and that the group's meeting time was established at a time when that student could not attend! In addition, the student in question had made himself available at other times (evenings and weekends) that the group was unwilling to meet. In effect, the group had created an untenable situation for the other member, but had attributed the other member's inability to meet to an internal cause!

\section{Group Attributions}

Just as groups control and influence the behaviors of their members, they influence their attributions as well. The most frequently studied aspects of group attributions have been those made by members of in-groups versus out-groups. One study found: “...people with strong group identification make more use of group-serving attributions than do people who do not identify as strongly." Furthermore, present findings also provide evidence that the process of attribution for one's own actions, as described in the self-attribution literature, and the process of attribution for the actions of fellow group members appear to be quite similar (DeCremer, 2000). Another study concluded: "Although in-group favoritism was not consistent enough to produce a group categorization effect, it is clear that those subjects who biased their evaluations also slanted their attributions (Finchilescu, 1994)." Still another one concluded: "Members of both groups displayed a tendency to attribute negative in-group behavior to external characteristics and negative out-group behavior to internal characteristics (Finchliescu, 1994)." Finally, a study found "a partial self-serving bias effect as individuals in successful groups assumed higher personal responsibility than those in failure groups (Urban and Witt, 1990)."

Both group and individual attributions are subject to errors. If professors make inaccurate attributions about their students, they may pursue the wrong course of action. Wrong attributions may lead to some minor turmoil or even to a major problem. These issues have led to my interest in further studying the attributions made by students about students, especially with regards to social loafing or being a slacker in a group.

\section{The 2001 Study}

Informal feedback from students about group work was becoming increasingly negative in nature. Students were saying that there was too much group work, that it was too difficult for them to get together outside of the classroom, that projects were too large and difficult, and that dealing with "slackers" was too taxing in terms of time and effort. During the summer of 2001, I did exploratory survey research in an attempt to learn about those issues and more. A convenience sample of students responded to open-ended questions about the characteristics of the best and worst group experiences, how the group dealt with social loafing and so on. Some of those results will be presented so that research conducted in 2002 will be in context.

In response to the question, What makes a group BEST?, the most frequent responses (at least $15 \%$ of respondents) were as follows: (1) worked together, equal share of work (18\%); (2) group participation, equal and fully (16\%); and (3) committed, motivated, and competent group members (15\%). The three responses are saying very similar things, i.e., we want a group where members pull their own weight and contribute to the finished product.

In response to the question, What makes a group WORST?, the most frequent responses were as follows: (1) one to three people doing the work (20\%) and (2) lack of commitment by group members (18\%). A majority of the responses to this question were about some aspect of social loafing. 
In response to the question, How did your group deal with social loafing, the most frequent responses were as follows: (1) Bite the bullet! Do extra work and pick up the slack (27\%); (2) graded them down on peer evaluations (18\%); and reported them to the professor (16\%). Of course, none of these responses was an effective way to deal with social loafing! Doing the work of another person merely adds to one's anger; using the performance rating comes too late, and reporting them to the professor may be pointless as some professors have no way of dealing with the social loafer. Ultimately, however, the students appeared to hold the professor responsible for social loafing by students. Of course, this could be a critical issue when students evaluate the professor's effectiveness. These findings led to survey research during the summer semester of 2002.

\section{The 2002 Study}

It seems to be a fact that in a group setting not all members will perform to $100 \%$ of their capabilities. This is true for student groups as well. This is a true case of attribution theory, in that each of us must decide if the cause is internal to the students or endemic to the situation. Based on our attribution as to cause, we will develop strategies for dealing with it. If we think it is internally caused, we might take a more motivational approach in designing the project and the relations that we foster with students. If we think it is externally caused, we will try to design controls to reduce social loafing. If we could only find that "big stick" or the "right carrot," our job would be easier.

This time the study was focused on social loafing and attributions related to it. The sample was a convenience sample of 26 students enrolled in strategic management course in the summer of 2002. Each student participated as a member of a group of six or seven students that completed a strategic audit of a publicly traded restaurant. During the summer session, lasting eight weeks, they rated the performance of fellow group members twice. The first time was at the midway point when no group grades had been earned yet. The groups were actively engaged in the strategic audit, but had not completed it. The second rating occurred after grades had been awarded for two components of the project, the external and internal analyses. At this point, the only group grade that was unknown to the students was the case presentation grade.

For this preliminary study, the first survey form contained questions about each student's experiences with groups. First, what percentage of those experiences had a social loafer? Second, what percentage of those experiences were you, the student, a social loafer? Third, what percentage of the time in those experiences did the professor have an effective method of dealing with social loafing? Fourth, and finally, why do you think that some students slack off in groups? The latter question was included to gauge the attributions made about a negative behavior.

Other data that were collected included: student satisfaction with the group experience ratings, their rating of their personal contribution to the group, and the average score for the project and the course. The measurement of these factors should contribute to our understanding of the situation, and subsequently, and attributions.

\section{Results}

Nearly $55 \%$ of the students' experiences with group projects amounting to at least $20 \%$ of the total grade included a social loafer or slacker. This represents a large pool of experience from which to assess social loafing. Regarding the percentage of times that the student had been a social loafer, 14 of 26 (54\%) reported having never been a slacker, 10 of 26 (38\%) reported having slacked 1 to $25 \%$ of the time, and 2 of 26 (8\%) reported slacking 26 to $50 \%$ of the time. While it would be possible to calculate a mean, it would not be a meaningful statistic. The primary use of this data will be to compare the attributions of those who self-reported themselves as not slacking versus those who did report themselves as slacking.

Regarding the amount of time that professors had an effective method for dealing with slackers in their group projects, the results were: zero percent of the time, $27 \%$; 1 to $25 \%, 54 \% ; 26-50 \%, 8 \%$; $51-75 \%$, $4 \%$; and $76-$ $100 \%, 8 \%$. The mean was $19 \%$. Basically, these percentages mean that students have a low opinion of the effectiveness of the way professors deal with social loafing in their group assignments. 
In terms of attributions, the 26 students made a total of 34 of them of which 23 were internal and 11 were external. Five students made one external and one internal attribution, while 15 students made internal attributions, and six made external attributions. I classified the student's comments as internal or external. A representative sample of internal attributions is as follows: they don't care, they know they can rely on others, they use others, they let others do it, they have a lack of knowledge, they are lazy, they are lazy and stupid, they procrastinate, and they don't care. In general, the internal attributions were what would be expected.

A sample of external attributions is as follows: the group controls the work and grade, the group excludes less knowledgeable, the group is overbearing, the group cannot control slackers, they have family issues, those with greater than four members will have a slacker, work schedules, group enables slackers, and leaders do too much. Nearly half of these attributions blamed the group for its slacking members! It was surprising that students accused the group of causing slacking, but it is consistent with attribution theory that they did so.

What was the impact of slacking experience on attributions made? Of those fourteen members that selfreported not having been a slacker, three members made both internal and external attributions while ten made only internal attributions and one made an external only attribution. Only those with self-reported slacker experience made external only attributions. In a preliminary way, it seems that "experienced" slackers needed to rationalize their behavior. One amusing, but telling, incident occurred during the two ratings of group members. Each time the students were asked to identify the slackers in their groups, if any. One student identified himself as a slacker. Later they were asked to award a bonus to one deserving member of the group. The self-identified slacker awarded himself a bonus!

The following table contains some interesting group results. First, the number of slackers ranged from 1 in two groups to three in one group! The group with three slackers performed the worst on all measures: satisfaction, personal contribution, and average scores. Surprisingly, the group with the two slackers ranked second in performance on project and total scores. Satisfaction levels were high as was the self-reported personal contribution to group rating.

Table 1. Group Results

\begin{tabular}{|l|c|c|c|c|c|}
\hline Group Name: & $\begin{array}{c}\text { Satisfaction Rat- } \\
\text { ing: }\end{array}$ & $\begin{array}{c}\text { Personal } \\
\text { Contribution: }\end{array}$ & $\begin{array}{c}\text { Average } \\
\text { Project Score: }\end{array}$ & $\begin{array}{c}\text { Average } \\
\text { Total Score: }\end{array}$ & $\begin{array}{c}\text { \# of Slackers } \\
\text { In Group }\end{array}$ \\
\hline Graduates & 4.5 & 4.5 & .87 & .91 & 1 \\
\hline A Team & 4.7 & 4.3 & .848 & .86 & 1 \\
\hline Lucky 7 & 4.4 & 4.1 & .847 & .85 & 3 \\
\hline “?" & 4.6 & 4.8 & .88 & .90 & 2 \\
\hline
\end{tabular}

\section{Discussion}

Of course the results are preliminary and the sample is too small, and not random, for theory building. One byproduct of this research has been considerable discussion about social loafing during the semester. We talked about it early and often. Students are more open about identifying those who engage in it and mark them down on group evaluations. Group members are more apt to challenge the work habits of reluctant members and to at least try social pressure on them.

In the past, I have allowed groups to fire members that do not do their part on the project. This past summer session there was no talk of firing and on the second rating only two groups still had a social loafer. The other two groups had one person each that maintained their slacker status. Social loafing is a detriment to group project work and anything that we can do to reduce it will have positive results.

Being a biased attributor myself (internal causes), I paid special attention to the assertions by students that some students are so oriented to earning high grades that they end up dominating and controlling group workload 
assignments. If this is true, then some groups may be causing at least the appearance of social loafing by a few members. Of course, I realize that these assertions may be weak rationalizations by those students who seek to become more comfortable with their personal slacking. If the latter statement is true, such students might be helped by an instructor spending more time on group formation and assisting them in becoming more assertive in taking on assignments. It would seem hard to believe that any group would initially turn away from offers of help from any of its members. Slacking appears as a pattern of failed promises, i.e., the promise to deliver something by a certain date and then not doing so or presenting work of dubious quality.

The process used to assign students to groups would seem to be an important variable in future research. For example, my groups form voluntarily. On the surface this would imply that students are well-acquainted with each other. In reality, ours is a commuter school with many students working full or part time so they tend to know few other students in the class. Other ways of assignment will be considered in future research.

\section{References}

1. Argyris, Chris. "Teaching Smart People How to Learn," Harvard Business Review, November-December, 1974, 144-158.

2. Bowen, Donald D.and Jackson, Conrad N. "Curing those Ol 'Olmigod-Not-Another-Group-Class' Blues," The Organizational Behavior Teaching Review, 1985/86; Vol. 10, No.4, 21-31.

3. DeCremer, David. "Effect of Group Identification on the Use of Attributions," Journal of Social Psychology, April, 2000, Vol. 140, No.2, 267-270.

4. Finchileseu, Gillian. "Intergroup Attributions in Minimal Groups," Journal of Social Psychology, February, 1994, Vol. 134, No. 1, 111-119.

5. Dixon, Andrea L., Spiro, Rosann L., and Jamil, Magbul. "Successful and Unsuccessful Sales Calls: Measuring Salesperson Attributions and Behavioral Intentions," Journal of Marketing, July, 2001, Vol.65, No. 3, 64-78.

6. Gibson, James L., Ivancevich, John M., Donnelly, James H. and Konopaske, Robert. Organizations: Behavior, Structure, Processes. McGraw-Hill, New York, 2003.

7. Hunter, John A. and Stringer, Maurice. "Intergroup Attribution and Social Identity," Journal of Social Psychology, December, 1992, Vol. 132, No. 6, 795-797.

8. Lengnick-Hall, Cynthia A. and Sanders, Martha M. "Designing Effective Learning Systems for Management Education: Student Roles, Requisite Variety, and Practicing What We Teach," The Academy of Management Journal, December, 1997, Vol. 40, No. 6, 1334-1368.

9. Morevic, Milan. "Self-managed Teams," Executive Excellence, October, 1999, Vol. 16, No. 10, 18.

10. Rusth, Douglas B. "Student Teams and Learning Achievement," Journal of Business Education, Fall, $2000,18-23$.

11. Schermerhorn, John R., Hunt, James G., and Osborn, Richard N. Organizational Behavior. John Wiley and Sons, Inc., New York, 2000.

12. Serna, Barbara. "My Student Project Leader Experience," IEEE Transactions on Professional Communication, December, 1988, Vol. 31, No. \$, 195-197.

13. Urban, Mark S. and Witt, Alan L. "Self-serving Bias in Group Member Attributions of Success and Failure," Journal of Social Psychology, June, 1990, Vol. 130, No. 3, 417-419.

14. Watson, Warren E., Johnson, Lynn, and Merritt, Deanna. "Team Orientation, Self-orientation, and Diversity in Task Groups," Group and Organizational Management, June, 1998, Vol. 23, No. 2, 161-188.

15. Zacharakis, Andrew L., Meyer, G. Dale, and DeCastro, Julio. "Differing Perceptions of New Venture Failure: A Matched Exploratory Study of Venture Capitalists and Entrepreneurs, Journal of Small Business Management, July, 1999, Vol. 37, No. 3, 1-17. 